\title{
Dental Caries in 6-12-Year-Old Indigenous and Non-Indigenous Schoolchildren in the Amazon Basin of Ecuador
}

\author{
Widman MEDINA ${ }^{1}$ \\ Anna-Karin HURTIG ${ }^{1,2}$ \\ Miguel SAN SEBASTIÁN ${ }^{1,2}$ \\ Edy QUIZHPE ${ }^{1}$ \\ Cristian ROMERO ${ }^{1}$

\begin{abstract}
${ }^{1}$ Instituto de Epidemiología y Salud Comunitaria "Manuel Amunárriz", Quito, Ecuador University of Umea, Umea, Sweden
\end{abstract} \\ ${ }^{2}$ Umea International School of Public Health, Department of Public Health and Clinical Medicine,
}

\begin{abstract}
The purpose of this study was to evaluate the caries experience among 6-12-year-old indigenous (Naporunas) and non-indigenous (recent settlers of mixed ethnic origin) schoolchildren, living in the Amazon basin of Ecuador. Cross-sectional data were obtained from 1,449 clinical exams according to the World Health Organization criteria. Nine (7.6\%) indigenous and $3(4.5 \%)$ non-indigenous children had no caries experience in their primary dentition at the age of 6 . The mean dmft value (SD) among indigenous and non-indigenous children aged 6 was 6.40 (3.36) and 8.36 (3.93), respectively. Sixty-four (54.2\%) indigenous and 29 (43.3\%) non-indigenous children had no caries experience in their permanent first molars at the age of 6. Only $7(6.26 \%)$ indigenous and $2(2.60 \%)$ non-indigenous children were caries-free at the age of 12. The mean DMFT values (SD) for 12-year-olds were 4.47 (2.85) among indigenous and 5.25 (2.89) among non-indigenous children. Fillings were almost non existent. Caries rates were high among both groups, with untreated carious lesions predominating in all ages. The data of indigenous children suggest adoption of a non-traditional diet. An appropriate oral health response based primarily on prevention and health promotion is needed.
\end{abstract}

Key Words: dental caries, schoolchildren, Amazon, Ecuador.

\section{INTRODUCTION}

Little information on the epidemiology of caries in Ecuador is available. National data from 1996 showed that caries rates at the ages of 6 and 12 were $87 \%$ and $85 \%$, respectively. The mean DMFT (decayed, missing and filled teeth) index in the 6-year-old range was 0.22 and 2.95 in the 12-year-old range. These data indicate a decrease in DMFT compared to the indices recorded in 1988 (0.70 and 5.00, respectively) (1) and Ecuador further reached the World Health Organization (WHO) 2000 year goal of a mean DMFT of 3 or less among 12year olds (2).

The decrease of DMFT index most likely reflects an improvement in oral health education and dental services. However, regions of a country may have different dental caries experiences compared to national data due to distinct living conditions and access to dental care. Following trends in countries and regions is important $(2,3)$, but does not fill the gap in information often existing within a country.

No information on dental status is available from the Amazon region of Ecuador. This region has been marginalized during decades and suffers from poorer infrastructure and health services than the rest of the country $(4,5)$.

The purpose of this study was to provide updated data and add to the sparse information available on the

Correspondence: Dr. Anna-Karin Hurtig, Umea International School of Public Health, Department of Public Health and Clinical Medicine, University of Umea, 90185 Umea, Sweden. Tel:+46-90-785-11-64. Fax: +46-90-13-89-77. e-mail: anna-karin.hurtig@epiph.umu.se 
caries experience in Ecuador by describing the caries prevalence among 6-12-year-old schoolchildren of indigenous (Naporunas) and non-indigenous origin living in the Amazon basin of Ecuador. The term non-indigenous is used for recent settlers from the country's coastal and highland regions, most of mixed ethnic origin so called "mestizos". The study formed part of a primary health care (PHC) program.

\section{MATERIAL AND METHODS}

The study was carried out in the Francisco de Orellana and Aguarico districts of the Orellana province in the north-eastern part of Ecuador. The population is around 46,700, of whom approximately 12,600 are indigenous and the rest are non-indigenous individuals (6). There are approximately 11,500 children in the 612 -year-old age group living in this region. The indigenous and non-indigenous groups of children live in separate villages and attend different schools.

The indigenous children attend bilingual schools at which teaching is given both in their local language as well as in Spanish. The non-indigenous children have their classes only in Spanish. School attendance in both groups is between $95-98 \%$ and absences are rare. Most part of the non-indigenous population live in small villages where trading and oil industry-related services are the main activities. Some of them, however, live in small communities where subsistence farming is the basis of the economy. Indigenous communities are scattered in the rainforest often without road access. They lack basic amenities, such as electricity, and water is collected from the rain or streams. Access to medical services is usually difficult (7).

In 1991, both indigenous and non-indigenous people started a PHC program in 60 communities with training of community health workers. In 1998, the PHC program was expanded to include oral health. The present study was conducted in order to obtain information on caries experience among schoolchildren before community activities were initiated.

Data were collected between May and July, 1998. Seventeen schools of non-indigenous and sixteen schools of indigenous communities in the Orellana and Aguarico counties representing typical rural communities were visited. The schools were chosen because they were located in the villages scheduled to be visited by the PHC program during these months. All children present were examined. Written informed consent was given by parents, community leaders and teachers before the study was conducted. The clinical examinations were carried out by two dentists who used the WHO criteria for diagnosis of dental caries (8). The DMFT values were derived from these criteria. The participants were examined while sitting in a school chair with the use of a dental mirror and blunt dental probe. Caries diagnosis was based solely on clinical examination and only caries at or beyond the dentinal level was recorded.

Data was entered into EPI-Info 6 statistical package (Centers for Disease Control and Prevention, Atlanta, GA, USA). Significance testing was performed using Kruskal-Wallis test because of the non-normal distribution of the variables studied.

\section{RESULTS}

A total of 1,805 children were present on the day of the examination. Complete data were available in $1,698(94.1 \%)$ cases. Two hundred and forty-nine pupils were excluded from analysis because they were not aged 6 to 12 years. This reduced the sample to 1,449 children. Nine hundred and thirty children (64.9\%) were indigenous and the remaining were non-indigenous (Table 1).

The status of the primary teeth was evaluated among children in the 6-year-old age range. A total of $9(7.6 \%)$ indigenous and $3(4.5 \%)$ non-indigenous children had no caries experience in their primary dentition at the age of 6 (Table 2). The dmft index was significantly lower among indigenous children $(p<0.001)$. The mean dmft indices (SD) recorded for indigenous and non-indigenous children at the age of 6 were 6.40 (3.36) and 8.36 (3.93), respectively. The dt component was the most important, being 5.07 (2.8) and 6.27 (3.39), respectively. Missing teeth were more common among non-indigenous [2.06 (2.97)] compared to indigenous [1.32 (1.74)] children. Fillings were almost non-existent.

The permanent teeth were evaluated among all 6-12 year-old children. Sixty-four (54.2\%) indigenous and $29(43.3 \%)$ non-indigenous children had no caries experience in their first molars at the age of 6. Only 7 $(6.25 \%)$ indigenous and $2(2.60 \%)$ non-indigenous children were caries-free at the age of 12 (Table 2). The 
DMTF indices increased in both indigenous and nonindigenous children as age increased (Table 3 ). The DMFT for 12-year-olds were 4.47 (2.85) among indigenous and 5.25 (2.89) among non-indigenous.

Overall, non-indigenous children had a significantly higher mean DMFT index than indigenous chil-

Table 1. Sample distribution stratified by ethnic group and age.

\begin{tabular}{lccc}
\hline & Indigenous & Non-Indigenous & Total \\
\hline 6-year-old & 118 & 67 & 185 \\
7-year-old & 157 & 60 & 217 \\
8-year-old & 141 & 93 & 234 \\
9-year-old & 146 & 66 & 212 \\
10-year-old & 149 & 79 & 228 \\
11-year-old & 107 & 77 & 184 \\
12-year-old & 112 & 77 & 189 \\
Total & 930 & 519 & 1449 \\
\hline
\end{tabular}

dren, depending primarily on their higher prevalence of decayed teeth. Fillings were uncommon in both groups. More than $55 \%$ of the 12-year-old indigenous children had more than 3 teeth affected by caries or its sequalae. In the non-indigenous children this percentage reached almost $70 \%$.

Table 2. Children with no caries experiences.

\begin{tabular}{ccc}
\hline & $\begin{array}{c}\text { Indigenous } \\
\mathrm{n}(\%)\end{array}$ & $\begin{array}{c}\text { Non-Indigenous } \\
\mathrm{n}(\%)\end{array}$ \\
\hline 6-year-old* & $9(7.63)$ & $3(4.48)$ \\
6-year-old & $64(54.24)$ & $29(43.28)$ \\
7-year-old & $42(26.75)$ & $12(20.00)$ \\
8-year-old & $37(26.24)$ & $12(12.90)$ \\
9-year-old & $22(15.07)$ & $8(12.12)$ \\
10-year-old & $23(15.44)$ & $7(8.86)$ \\
11-year-old & $5(4.67)$ & $5(6.49)$ \\
12-year-old & $7(6.25)$ & $2(2.60)$ \\
\hline
\end{tabular}

$* \mathrm{dmft}=0$

Table 3. Dental caries and treatment experiences of children aged 6-12 by ethnic group. Mean (SD) DMFT index.

\begin{tabular}{|c|c|c|c|c|c|c|c|c|}
\hline & \multicolumn{2}{|c|}{ DMFT } & \multicolumn{2}{|c|}{$\mathrm{D}$} & \multicolumn{2}{|c|}{ M } & \multicolumn{2}{|c|}{$\mathrm{F}$} \\
\hline & Indigenous & $\begin{array}{c}\text { Non- } \\
\text { Indigenous }\end{array}$ & Indigenous & $\begin{array}{c}\text { Non- } \\
\text { Indigenous }\end{array}$ & Indigenous & $\begin{array}{c}\text { Non- } \\
\text { Indigenous }\end{array}$ & Indigenous & $\begin{array}{c}\text { Non- } \\
\text { Indigenous }\end{array}$ \\
\hline Total & $2.95(2.69)$ & $3.46(2.74)^{*}$ & $2.80(2.51)$ & $3.24(2.59)^{*}$ & $0.12(0.46)$ & $0.14(0.49)$ & $0.03(0.06)$ & $0.07(0.17)^{*}$ \\
\hline 6-yr-old & $0.78(1.03)$ & $1.08(1.21)$ & $0.78(1.03)$ & $1.08(1.21)$ & $0.00(0.00)$ & $0.00(0.00)$ & $0.00(0.00)$ & $0.00(0.00)$ \\
\hline 7-yr-old & $1.87(1.52)$ & $2.18(1.42)$ & $1.85(1.50)$ & $2.08(1.38)$ & $0.02(0.18)$ & $0.03(0.18)$ & $0.00(0.00)$ & $0.07(0.36)^{* *}$ \\
\hline 8-yr-old & $1.89(1.58)$ & $2.94(1.57)^{*}$ & $1.84(1.57)$ & $2.90(1.59)^{*}$ & $0.04(0.19)$ & $0.01(0.10)$ & $0.01(0.17)$ & $0.02(0.15)$ \\
\hline 9-yr-old & $2.62(1.70)$ & $2.77(1.57)$ & $2.52(1.66)$ & $2.54(1.49)$ & $0.06(0.26)$ & $0.11(0.47)$ & $0.04(0.31)$ & $0.12(0.51)$ \\
\hline $10-$ yr-old & $3.19(2.38)$ & $3.30(2.02)$ & $3.06(2.30)$ & $3.08(2.04)$ & $0.13(0.39)$ & $0.13(0.40)$ & $0.00(0.00)$ & $0.10(0.41)^{*}$ \\
\hline 11-yr-old & $4.41(2.57)$ & $4.61(3.03)$ & $4.23(2.52)$ & $4.23(2.91)$ & $0.18(0.47)$ & $0.23(0.58)$ & $0.00(0.00)$ & $0.14(0.77)^{*}$ \\
\hline 12-yr-old & $4.47(2.85)$ & $5.25(2.89)$ & $4.19(2.63)$ & $4.87(2.71)$ & $0.23(0.57)$ & $0.29(0.69)$ & $0.05(0.30)$ & $0.09(0.33)$ \\
\hline
\end{tabular}

$* \mathrm{p}<0.01 ; * * \mathrm{p}<0.05$ 


\section{DISCUSSION}

This study shows that caries prevalence was substantially higher in the Amazon region than official averaged national data (1). Caries rates are high with untreated lesions dominating all ages. The results reflect low incorporation of dental services in the region. The DMFT value among 6-year-old schoolchildren is high and indicates a very rapid destruction of the first permanent teeth. The overall caries prevalence was almost as high among indigenous as non-indigenous children. This suggests that both populations are adopting a non-traditional diet. The traditional diet among indigenous consists of cassava, bananas, fish and game meat and among non-indigenous rice, cassava and meat from their small farms.

Studies among indigenous populations from the Brazilian Amazon from the 1960s reported a very low prevalence of dental caries $(9,10)$. However later studies have indicated that Brazilian indigenous populations now experience a high prevalence due to incorporation of industrialized foodstuffs in their diet combined with lack of dental services and preventive programs $(11,12)$.

The recorded prevalence of untreated dental caries in schoolchildren in the Amazon basin of Ecuador actually requires an appropriate oral health response based primarily on prevention and health promotion. Given the lack of comprehensive government services in this marginalized region there is a continuous need for non-governmental activities.

\section{RESUMO}

O propósito deste estudo foi avaliar a experiência de cárie entre escolares indígenas (Naporunas) e escolares não-indígenas (colonizadores recentes de origem étnica variada) com idades entre 6 e 12 anos, residentes na bacia amazônica do Equador. Os dados transversais foram obtidos a partir de 1.449 exames clínicos realizados de acordo com os critérios da Organização Mundial da Saúde (OMS). Nove (7,6\%) crianças indígenas e 3 (4,5\%) crianças não-indígenas não tiveram experiência de cárie na dentição decídua aos 6 anos. $\mathrm{O}$ valor médio do ceo-d (SD) entre os escolares indígenas e não-indígenas com idade de 6 anos foi de $6,40(3,36)$ e 8,36 (3,93), respectivamente. Sessenta e quatro $(54,2 \%)$ escolares indígenas e $29(43,3 \%)$ escolares não-indígenas não tiveram experiência de cárie nos primeiros molares permanentes aos 6 anos. Apenas $7(6,26 \%)$ entre as crianças indígenas e $2(2,6 \%)$ entre as não-indígenas não apresentaram cárie aos 12 anos. Os valores médios de CPO-D para os escolares aos 12 anos foram de $4,47(2,85)$ entre os escolares indígenas e 5,25 $(2,89)$ entre os escolares não-indígenas. As restaurações foram praticamente ausentes. A incidência de cárie foi alta nos dois grupos, com predominância de lesões não tratadas em todas as idades. Os dados referentes aos escolares indígenas sugerem a adoção de uma alimentação não tradicional. Torna-se necessária uma resposta adequada de saúde oral, baseada principalmente na prevenção e promoção de saúde.

\section{ACKNOWLEDGEMENTS}

The authors are grateful to the community health workers organizations Fundación Salud Amazónica and Sandi Yura. The primary health care programme was funded by Medicus Mundi Andalucía, Spain.

\section{REFERENCES}

1. Pan American Health Organization, 2001. Ecuador. Country health profile. Available at <http://www.paho.org/english/sha/ prflecu.htm> Latest access February, 2008.

2. Beltran-Aguilar ED, Estupiñan-Day S, Baez R. Analysis of prevalence and trends of dental caries in the Americas between the 1970s and 1990s. Int Dent J 1999;49:322-329.

3. Bonecker $\mathbf{M}$, Cleaton-Jones $\mathbf{P}$. Trends in dental caries in Latin America and Caribbean 5-6 \& 11-13-yr-old children. A systematic review. Comm Dent Oral Epidemiol 2003;31:152157

4. Consejo Provincial de Orellana. Plan de Desarrollo Estratégico Participativo de la provincia de Orellana, 20052015 [Strategic Development Plan for Orellana province, 2005-2015]. Coca, Ecuador: Consejo Provincial de Orellana; 2005.

5. Teran C. Sucumbios 2000. Lago Agrio, Ecuador: Vicariato de Sucumbíos; 2000.

6. Instituto Nacional de Estadísticas y Censos del Ecuador. VI Censo de Población y V de Vivienda [VI Population census and V Household census]. Quito: INEC; 2001.

7. Consejo Cantonal de Salud de Orellana. Plan Estratégico Cantonal de Salud, 2007-2015 [County Stragegic Plan for Health, 2007-2015]. Coca, Ecuador: Consejo Cantonal de Orellana; 2007.

8. Oral health surveys. Basic Methods. 4th ed. Geneva: World Health Organization; 1997.

9. Neel JV, Salzano FM, Junqueira PC, Keiter F, Maybury-Lewis D. Studies on the Xavante Indians of the Brazilian Mato Grosso. Am J Hum Genetic 1964;16:52-140.

10. Niswander JD. Further studies on the Xavante Indians. VII. The oral status of the Xavantes of Simoes Lopes. Am J Hum Genetic 1967;19:543-553.

11. Normando AD, De Araujo IC. Prevalence of dental caries in a school population of the Amazonian region. Rev Saúde Pública 1990;24:294-299.

12. Rigonatto DDL, Antunes JLF, Frazao P. Dental caries experience of Indians of the Upper Xingu, Brazil. Rev Inst Med Trop São Paulo 2001;43:93-98. 